\title{
Central Nervous System Angiolipoma
}

National Cancer Institute

\section{Source}

National Cancer Institute. Central Nervous System Angiolipoma. NCI Thesaurus. Code C129538.

An angiolipoma that arises from the central nervous system. 